\title{
CrimRxiv
}

\section{Privacy and Security in the 21st CenturyWho Knows and Who Controls?: Proceedings of a Forum}

National Research Council

Published on: Jul 01, 2019

DOI: 10.21428/cb6ab371.ef693f51

License: Creative Commons Attribution 4.0 International License (CC-BY 4.0). 
